\title{
Basin and Range Carbonate Aquifer System Study
}

To better understand and evaluate regional ground-water flow systems in Nevada, and initiate long-term
studies of potential impacts from future ground-water pumping, Federal legislation was enacted in December
2004 (Section 301 (e) of the Lincoln County Conservation, Recreation, and Development Act of 2004; short title,
Lincoln County Land Act) that states,
"The Secretary, acting through the United States Geological Survey, the Desert Research Institute, and a desig-
nee from the State of Utah shall conduct a study to investigate ground water quantity, quality, and flow charac-
teristics in the deep carbonate and alluvial aquifers of White Pine County, Nevada, and any groundwater basins
that are located in White Pine County, Nevada, or Lincoln County, Nevada, and adjacent areas in Utah."

In response to the Lincoln County Land Act, the U.S. Geological Survey (USGS), in cooperation with the Desert Research Institute (DRI) and the Utah State Engineer's Office, identified the following objectives:

- Evaluate geohydrologic characteristics within the study area including the extent, thickness, and hydrologic properties of aquifers; volume and quality of water stored in aquifers; delineation of subsurface geologic structures controlling ground-water flow; ground-water flow direction and gradients; distribution of recharge and discharge areas; and representative rates of recharge and discharge.

- Integrate geologic, hydrologic, and geochemical information to determine basin and regional groundwater budgets.

- Synthesize and evaluate all geohydrologic data to develop a three-dimensional conceptual description of the ground-water flow system. These data will be used to create a unified data-collection network for the study area.

Study objectives are designed to be worked on simultaneously and to provide specific information needed to quantify basin ground-water budgets and to develop an improved understanding of regional ground-water flow.

To accomplish the objectives of this study, participants from the USGS Water Science Centers in Nevada and Utah, and the Geology Science Centers in Denver and Menlo Park; DRI in Reno and Las Vegas; and the Utah State Engineer's Office, will work cooperatively on separate but coordinated tasks.

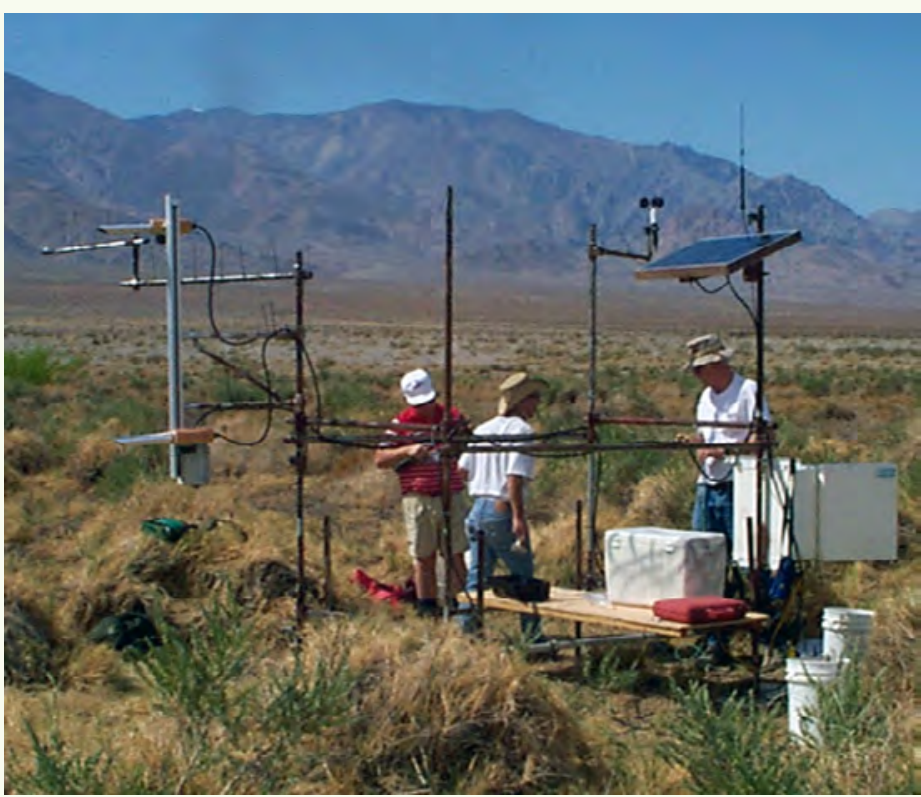

USGS scientists assemble an evapotranspiration station.

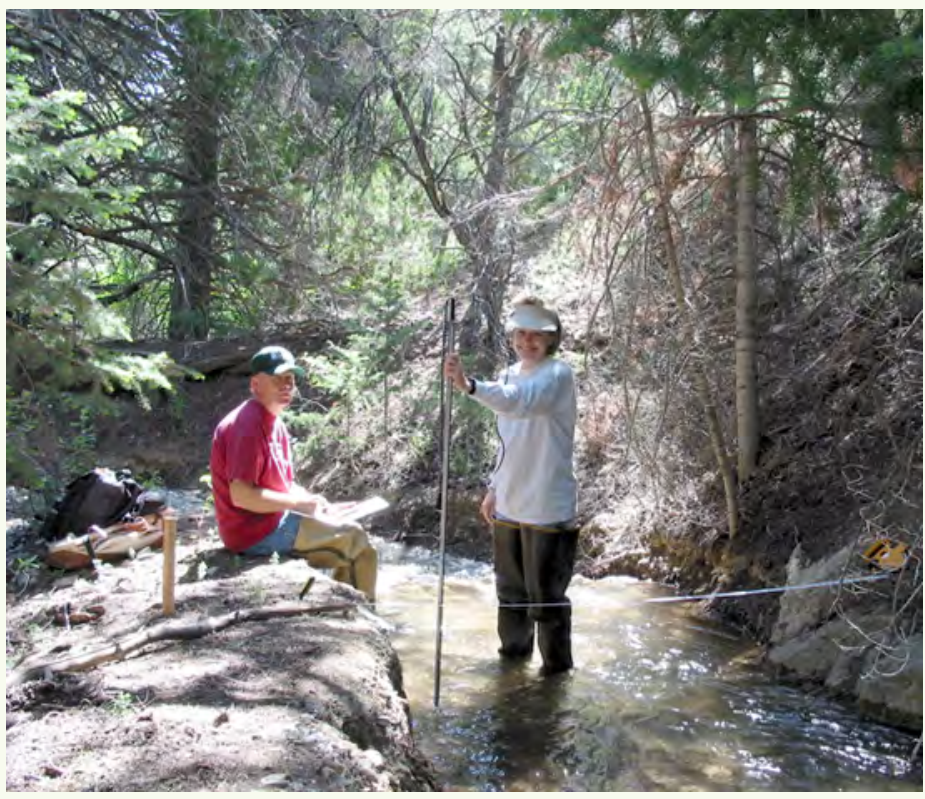

USGS scientists measuring streamflow. 


\section{Task 1 - Geology}

Evaluate hydrogeologic controls on ground-water flow through carbonate and alluvial aquifers. Determine the approximate volume of water stored in those aquifers by evaluating data on aquifer thickness, extent, and structural characteristics; and hydraulic properties.

\section{Task 2 - Recharge and Discharge}

Develop estimates of mean annual recharge and discharge, including discharge by evapotranspiration (ET), pumpage, streamflow, and springflow using geographic information system (GIS) analysis, the collection of new atmospheric data, and remote-sensing techniques.

\section{Task 3 - Ground-Water Flow}

Evaluate principal ground-water flow paths using existing and new water-level data that represent the regional groundwater flow system. Develop maps that represent the altitude of static water levels in wells within the flow system.

\section{Task 4 - Geochemistry}

Describe the chemical quality of ground water using existing data for major ions, trace metals, and pesticides. Collect and analyze new data to enhance the understanding and to support hydrologic evaluations of the magnitude and distribution of recharge, ground-water flow direction, and ground-water travel times.

\section{Task 5 - Data Integration}

Compile and collect existing and new hydrologic data from each task to be stored in the USGS National Water Information System (NWIS). Develop a central database for storage and dissemination of spatial data sets. Develop a public web site for dissemination of study information and data.

\section{Task 6 - Data Synthesis and Evaluation}

Synthesize and evaluate the results of all tasks to estimate basin water budgets, develop a three-dimensional conceptual description of regional ground-water flow, and prepare a final report documenting the results of the study.

Results of this study will provide needed information on the aquifer system in White Pine County to help water-resource agencies and interested stakeholders make informed decisions about future water-supply issues. Understanding the hydrologic characteristics and the factors that influence the inflows and outflows from the aquifer system is critical for evaluating how future groundwater development may impact such issues as spring discharge and associated ecosystems or the volume of ground water available to users. Potential impacts from pumping are best evaluated by using a numerical model to simulate ground-water flow; however, this simulation is not part of the current study. A calibrated transient ground-water flow model will not be constructed for the study area.

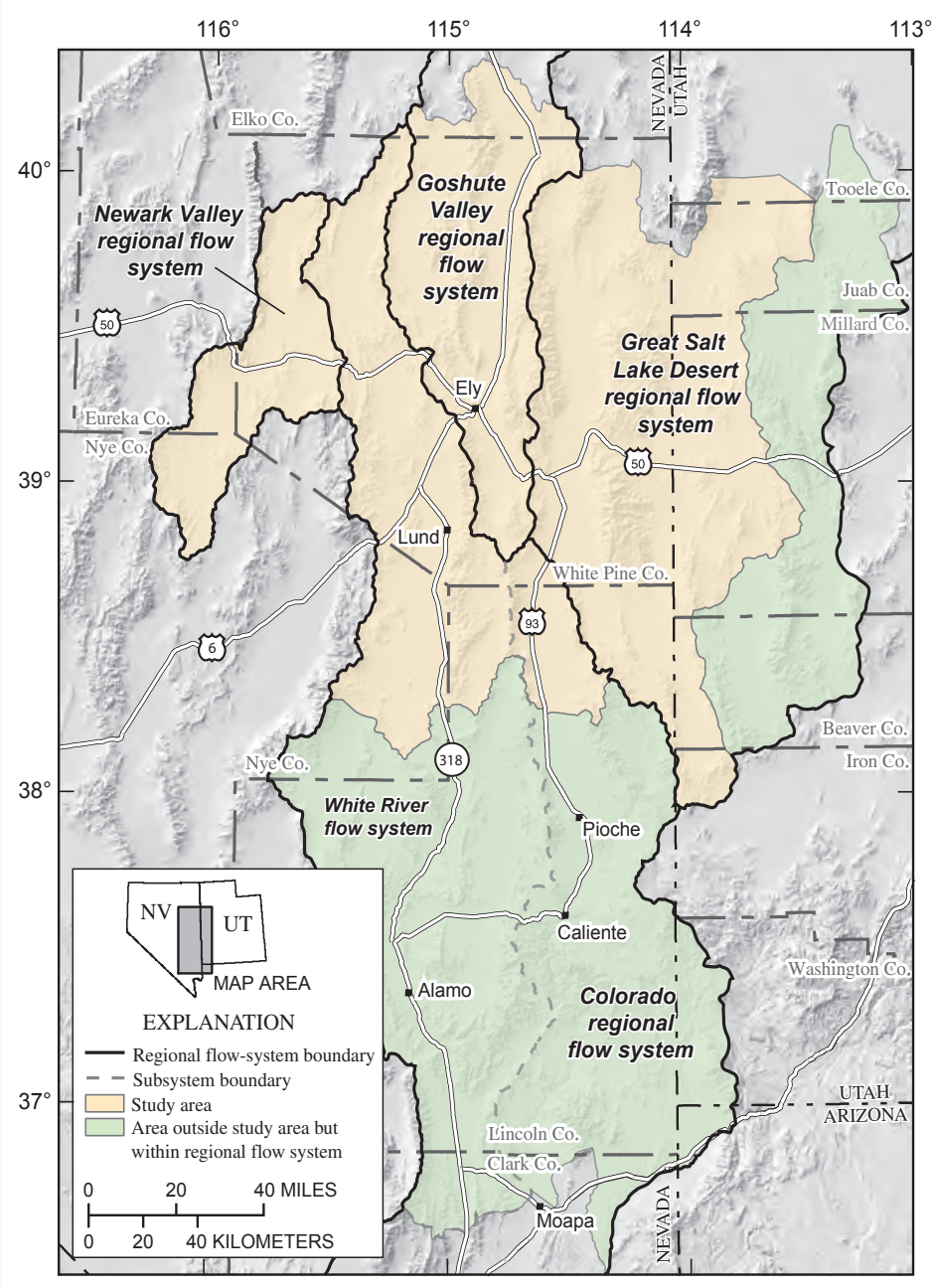

Base from U.S. Geological Survey 1:100,000-scale digital data, 1979-1984. Universal Transverse Mercator Projection, zone 11, North American Datum of 1927. Shaded-relief base 30-meter Digital Elevation Model; sun illumination from northwest at 30 degrees above horizon. Watershed boundaries from 1:1,000,000-scale U.S. Geological Survey digital data.

The conceptual description developed by this study, however, provides the necessary hydrogeologic information for future development of a ground-water flow model to better assess potential impacts, if any, to important discharge areas from proposed water-development strategies.

The study must be completed within 36 months beginning December 2004. The results of each task will be summarized into one USGS Scientific Investigations Report; the draft publication will be presented to Congress no later than June 1, 2007, and published no later than December 1, 2007.

For more information about this study, or other USGS water-resources studies in Nevada, please contact:

Kimball E. Goddard, Director

USGS Nevada Water Science Center

333 West Nye Lane, Room 203

Carson City, NV 89706--0866

Tel: (775) 887-7635

Fax: (775) 887-7621
Email: kgoddard@usgs.gov URL: http://nevada.usgs.gov 